The compounder has, of necessity, to give serious thought to the manufacture of these diets, and if he is willing to standardize in the way which $I$ have indicated then obviously the final products are of fairly regular composition. On the other hand, if a compounder gives little thought to the possible variation in the quality of his individual ingredients and uses whatever comes to hand, the difference in nutritional quality between one batch and another may be very wide and the results serious.

Concerning the actual manufacturing process, there is not a great deal which one can say. The principle is to inject steam into the dry meal with subsequent compression through a dye. Obviously one can produce pellets of variable size and we offer the modified diet 18 of Bruce $\&$ Parkes (1947) in the form of a $3 / 16$ in. pellet and the other as a $3 / 8$ in. pellet. The material is normally processed in 3 -ton batches.

Obviously it is very important to achieve a thorough mixing before pelleting, and to achieve it the meal is first of all mixed in a horizontal-drum type of mixer from which it is fed into a vertical fountain-type mixer and from there into the pelleting machine. The meal passes from the mixer into the cascader where another mix is achieved through the use of agitators, and during this process steam is injected; the meal is then compressed through a dye. The pellets then pass into an air-cooled vertical cooling chamber, and thence through sieves to the packer. The rate of takeoff depends on the size of the pellet being manufactured and is of the order of $45^{-5} 5^{\circ}$ $\mathrm{cwt}$./ $\mathrm{h}$ for the $3 / \mathrm{I} 6 \mathrm{th}$ in, size and $55^{-60} \mathrm{cwt}$. $/ \mathrm{h}$ for the $3 / 8 \mathrm{th}$ in. size. The meal in the cascader reaches a temperature of about $100^{\circ} \mathrm{F}$. Incidentally there is no binding material added. The pellets are packed in hessian sacks, as packing in such containers avoids the possibility of mould development in the event of the pellets sweating.

\title{
REFERENCES
}

Bruce, A. M. \& Parkes, A. S. (1947). F. Hyg., Camb., 45, 70.

Bruce, A. M. \& Parkes, A. S. (1949). F. Hyg., Camb., 47, 202.

\section{The assessment of the diets of laboratory animals}

\section{By Gwendoline G. Weeks, Laboratory Animals Bureau of the Medical Research Council, Holly Hill, Hampstead, London, N.W.3}

The title of this paper may appear to embrace too large a subject to be covered in one short paper. Therefore at the beginning I should like to qualify it and say that I am going to deal with criteria that have been used to assess the nutritional adequacy of diets for laboratory animals and then go on to describe a method I have used with special reference to the body composition of rats.

Growth is most commonly used as a criterion to assess the need for a nutritional factor in a diet, because normal growth imposes a great metabolic strain on an animal. 
The reproductive performance is an index of the nutritional state during pregnancy and lactation, provided strain differences and environmental factors are standardized. An animal may show good growth on a particular diet and yet be unable to reproduce on it.

The clinical assessment of a diet is often overlooked. It is related to mortality and morbidity rates and general resistance to disease. Howie (1948-9) points out that the relationship between diet and susceptibility to infection is not widely accepted among bacteriologists. He shows that the relationship is real and well worth investigating. The value of a diet in resistance tests was not always the same as that suggested by growth and reproduction tests (Sengupta \& Howie, 1948-9; Howie \& Porter, I950).

The methods chosen to assess a diet will be influenced by the type of animal and the purpose for which it is required at the end of the experiment.

\section{EXPERIMENTAL}

Twenty-six female Benger strain rats, aged 22 days, were divided into two groups, $A$ and B. Group A were the controls and were fed on cubed diet $4 \mathrm{I}$ (Bruce $\&$ Parkes, I949) supplemented with $5 \mathrm{~g}$ liver and $5 \mathrm{~g}$ cabbage/rat/week. Group B were given the experimental diet. The experimental diet was a basal diet supplemented with $10 \%$ fish meal. The basal diet consisted of wholemeal flour 80 , potato starch 10, haricot bean 5, lucerne meal 2, groundnut oil 2 and salts $1 \%$, with vitamins $A$ and D. This diet was prepared in biscuit form and was considered to provide all the known nutritional requirements for rat development. Ultimately it was hoped that this diet might provide a basis for a stock diet for rats. Both groups received food and water ad lib.

The rats were weighed three times a week for the rst month and thereafter once a week. At 9 months old the rats were killed. After death they were eviscerated;

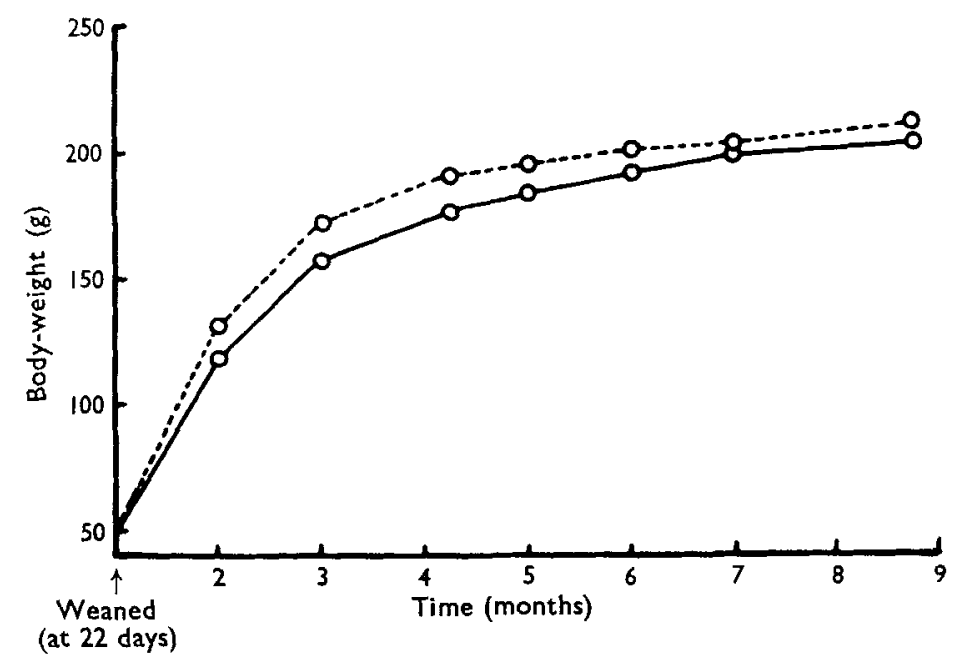

Fig. I. Mean growth curves for groups of thirteen fernale rats. $0 \ldots \ldots 0$, control diet; $0 \ldots \ldots$, experimental diet (see text, this page). 
the skin, tail, head and paws were removed and fat, water and nitrogen determinations were made on homogenized samples of the remaining carcass. This was done to give additional information on the nature of the weight gain shown in the growth curve. Fat and water were estimated by the method described by Kaye, Leibner \& Connor (1940). Nitrogen was determined by the Kjeldahl-Markham method (Kabat \& Mayer, 1948).

\section{RESULTS}

Fig. I shows the mean weight gains of the rats in groups A and B. Table I shows the percentage of fat, water and nitrogen present in the carcasses. The figures for water and nitrogen are given on a fat-free basis because the percentage of water and nitrogen are relatively constant in the fat-free body of mature animals under normal dietary régimes.

Table 1. Percentage of fat, water and nitrogen in the carcasses of twenty-six female rats

\begin{tabular}{|c|c|c|c|c|}
\hline \multicolumn{5}{|c|}{ Group A } \\
\hline $\begin{array}{l}\text { Rat } \\
\text { no. }\end{array}$ & $\begin{array}{l}\text { Weight } \\
\text { at } \\
\text { death } \\
\text { (g) }\end{array}$ & $\begin{array}{l}\text { Fat } \\
(\%)\end{array}$ & $\begin{array}{l}\text { Water } \\
\text { in fat- } \\
\text { free } \\
\text { sample } \\
(\%)\end{array}$ & $\begin{array}{l}\text { Nitrogen } \\
\text { in dry, } \\
\text { fat-free } \\
\text { sample } \\
(\%)\end{array}$ \\
\hline 64 & 222 & 9.9 & 73.9 & 10.2 \\
\hline 67 & 247 & I I.9 & $72 \cdot 3$ & $12 \cdot 2$ \\
\hline 73 & $25 \mathrm{I}$ & 10.1 & 60.7 & I I.4 \\
\hline 74 & 224 & $10 \cdot 3$ & $72 \cdot 0$ & $11 \cdot 6$ \\
\hline 79 & 268 & 16.0 & $72 \cdot 0$ & $12 \cdot 3$ \\
\hline 80 & 230 & $8 \cdot 4$ & $78 \cdot 5$ & $12 \cdot 5$ \\
\hline 107 & 244 & $8 \cdot 4$ & 73.8 & II. 4 \\
\hline 115 & 226 & 10.6 & $72 \cdot 3$ & $12 \cdot 2$ \\
\hline I 20 & $22 \mathrm{I}$ & $12 \cdot 2$ & $7 x \cdot 2$ & $\mathrm{I} \mathrm{I} \cdot 5$ \\
\hline I 2 I & г98 & $6 \cdot 7$ & $73 \cdot 0$ & 10.5 \\
\hline I 32 & 218 & $x I \cdot 4$ & $68 \cdot 2$ & $12 \cdot 3$ \\
\hline I 33 & I 88 & 8.0 & $76 \cdot 0$ & $\mathrm{II} \cdot 3$ \\
\hline 1003 & 220 & 9.8 & $72 \cdot 2$ & $12 \cdot 5$ \\
\hline Mean & $227 \cdot 5$ & $10 \cdot 3$ & $72 \cdot 0$ & I I $\cdot 7$ \\
\hline
\end{tabular}

\begin{tabular}{|c|c|c|c|c|}
\hline \multicolumn{5}{|c|}{ Group B } \\
\hline $\begin{array}{l}\text { Rat } \\
\text { no. }\end{array}$ & $\begin{array}{c}\text { Weight } \\
\text { at } \\
\text { death } \\
\text { (g) }\end{array}$ & $\begin{array}{l}\text { Fat } \\
(\%)\end{array}$ & $\begin{array}{l}\text { Water } \\
\text { in fat- } \\
\text { free } \\
\text { sample } \\
(\%)\end{array}$ & $\begin{array}{l}\text { Nitrogen } \\
\text { in dry, } \\
\text { fat-free } \\
\text { sample } \\
(\%)\end{array}$ \\
\hline 72 & $23 I$ & $6 \cdot 9$ & $71 \cdot 2$ & I I 0 \\
\hline 75 & 232 & $7 \cdot 3$ & $74 \cdot 1$ & 10.7 \\
\hline $\begin{array}{l}77 \\
81\end{array}$ & $\begin{array}{l}253 \\
208\end{array}$ & I 3.8 & $\begin{array}{l}71 \cdot 2 \\
68.6\end{array}$ & I I. 5 \\
\hline 83 & $\begin{array}{l}208 \\
228\end{array}$ & $\begin{array}{r}7 \cdot 0 \\
10 \cdot 1\end{array}$ & $\begin{array}{l}68 \cdot 6 \\
77 \cdot 1\end{array}$ & $\begin{array}{l}10.4 \\
12.0\end{array}$ \\
\hline 108 & 209 & $8 \cdot 1$ & $72 \cdot 4$ & $9 \cdot 3$ \\
\hline I I 6 & $24^{\circ}$ & $16 \cdot 3$ & $74 \cdot 6$ & II $\cdot 2$ \\
\hline 123 & 216 & 10.9 & $74 \cdot 1$ & IO.I \\
\hline I 24 & 199 & $7 \cdot 6$ & $68 \cdot I$ & 10.5 \\
\hline 125 & 207 & $9 \cdot 4$ & 72.8 & II .8 \\
\hline 130 & 190 & $6 \cdot 3$ & $70 \cdot 0$ & I $2 \cdot 1$ \\
\hline 131 & 185 & I I $\cdot I$ & 80.0 & II 6 \\
\hline 1004 & 232 & $8 \cdot 7$ & $68 \cdot I$ & 10.6 \\
\hline Iean & $217 \cdot 7$ & $9 \cdot 5$ & $72 \cdot 5$ & I I $\cdot 0$ \\
\hline
\end{tabular}

\section{DISCUSSION}

The control rats on the cubed diet gained more weight than those on the experimental diet. The difference in weight gain was significant after 2 months on the diet $(P=0.02)$ but not after 8 months $(P=0.2)$. The control group on the average had a slightly higher percentage of fat and nitrogen and a lower percentage of water. The difference between fat and water was not statistically significant (water $P=0.7$; fat $P=0.4$ ). The difference between the nitrogen content was just significant $(P=0.05)$. Although these figures do not reveal any startling differences in the body composition of the rats on the different diets, it is of interest to compare individual rats of similar weight. When rats nos. 67 and I 6 are compared it will be seen that no. 67 weighed more at death than no. I 6 and yet had less fat in the carcass. Rats 
nos. 80 and 72 weighed $230 \mathrm{~g}$ and $23 \mathrm{I} \mathrm{g}$, respectively, yet no. 80 had a higher percentage of fat.

The study of the body composition gives a measurement of the relative amounts of fat, water and protein that are formed in an animal under different dietary conditions. In addition to the method used, fat can be determined by the measurement of body density and by the use of fat-soluble indicators. The water can be measured by oven drying or over an absorbent (Haldi, Giddings \& Wynn, I94I-2) or by continuous extraction in a water-extraction apparatus as described by Dean \& Stark (1920) and by Kaye et al. (1940). In addition to direct analysis of the samples, nitrogen values can be calculated from the body water content (Bender \& Miller, 1953). Nitrogen-balance studies give an indication of the loss or gain in nitrogen in the living animal.

Brody (I945) defines growth as a 'relatively irreversible time change in magnitude of the measured dimension or function'. This definition covers growth in size as well as weight. Any measurements of growth should cover both aspects. An increase in weight is often used as a measure of growth. Size measurements, such as the length of the body, have been used in conjunction with weight gain. Both of these methods are useful but incomplete measurements of growth. They do not indicate the nature of the tissues formed and they are not suitable measures of co-ordinated development. To obtain a more complete picture of the growth process it is necessary to know the structural changes and chemical variations in the tissue and body fluids.

The development of bone cannot be measured by an increase in weight. Orr \& Richards (1934) showed that in vitamin A-deficient rats the bones had continued to increase in length while the animals were loosing weight. Methods that have been used to study skeletal growth are:

(I) Measurement of bones at autopsy (Orr \& Richards, 1934).

(2) X-ray analysis, a method by which bones can be measured in the living animal.

(3) Autoradiographic studies used, e.g., by Tomlin, Henry \& Kon (r953) to measure growth and calcium metabolism in the long bones of the rat.

(4) Measurement of the availability of the calcium and phosphorus in the diet by analysis of the bone ash.

(5) Estimation of calcification of bones by comparison of their densities.

(6) Observation of the appearance of ossification centres, used by Mackay (1952) as an index of growth.

(7) Calcium- and phosphorus-balance experiments, which indicate the progress of bone development in the living animal.

McCay, Crowell \& Maynard (1935) have challenged the view that rapid growth, as measured by an increase in weight and size, is ideal for long life and health. The evidence on this subject is rather conflicting and in terms of the production of laboratory animals is a debatable point, but it does serve to indicate the need for investigation of nutritional factors involved in the length of life and the life-time performance. 


\section{CONCLUSTON}

Growth, as measured by weight gain, and reproductive performance are the most common factors used in assessing a diet. Often reproductive performance is given on the results with one or two litters. The desirability of rapid growth has been a dominant idea in current nutritional thought, and recent discoveries have resulted in feeding practises that have accelerated the growth rate as measured by weight gain. However, some animals with a promising growth performance fail to come into profitable production, or have a short reproductive life. It cannot be said that all factors for growth are optimal until their influence on the life-time performance has been studied as thoroughly as their effects during the growth period itself.

It would seem that in the past too much emphasis has been put on weight and size in judging the value of a diet for promoting growth with less consideration of the actual composition of the changes in form. With breeding stock the life-time performance is the final measure of success and it is important to consider several aspects of growth and their influence on the life-time performance. Therefore before a diet can be described as being adequate for maintenance and reproduction it should be tested through all these aspects.

I should like to thank Dr W. Lane-Petter and Professor B. S. Platt for the help and advice they have given me in the preparation of this paper and during the actual course of the work.

\section{REFERENCES}

Bender, A. E. \& Miller, D. S. (1953). Biochem. F. 53, vii.

Brody, S. (1945). Bioenergetics and Growth. New York: Reinhold Publishing Corp.

Bruce, H. M. \& Parkes, A. S. (1949). I. Hyg., Camb., 47, 202.

Dean, E. W. \& Stark, D. D. (1920). F. indust. Engng Chem. 12, 486.

Haldi, J., Giddings, G. \& Wynn, W. (r941-2). Amer. F. Physiol. r35, 392.

Howie, J. W. (1948-9). Brit. F. Nutr. 2, 33r.

Howie, J. W. \& Porter, G. (1950). Brit. F. Nutr. 4, 175.

Kabat, E. A. \& Mayer, M. M. (1948). Experimental Immunochemistry. Springfield, Ill.: Charles C. Thomas.

Kaye, I. A., Leibner, I. W. \& Connor, E. B. (I940). F. biol. Chem. 132, 195.

Mackay, D. H. (I952). Trans. R. Soc. trop. Med. Hyg. 46, 135.

McCay, C. M., Crowell, M. F. \& Maynard, L. A. (1935). J. Nutr. 1o, 63.

Orr, J. B. \& Richards, M. B. (1934). Biochem. F. 28, 1259.

Sengupta, S. R. \& Howie, J. W. (1948-9). Brit. F. Nutr. 2, 3 I3.

Tomlin, D. H., Henry, K. M. \& Kon, S. K. (1953). Brit. F. Nutr. 7, 235.

\section{Nutrient requirements of rats and mice}

\section{By W. F. J. Cuthbertson, Glaxo Laboratories Ltd, Greenford, Middlesex}

Nutrient requirements may be assessed in several ways: the quantity of a specific nutrient needed to abolish or prevent the appearance of a specific deficiency disease 